\title{
ECHO 9 infection in pregnant women with suspected rubella
}

\author{
ELEANOR J. BELL, CONSTANCE A. C. ROSS ${ }^{1}$, AND N. R. GRIST \\ From the Regional Virus Laboratory and Glasgow University Department of Infectious Diseases, \\ Ruchill Hospital, Glasgow
}

SYNOPSIS Both rubella virus and Echovirus 9 (ECHO 9) were epidemic in Scotland during the summer of 1973; both viruses can cause a mild febrile illness with rash. Sera from 386 rubella-negative pregnant women were tested for neutralizing antibodies to ECHO 9 virus; 40 women had antibody titres suggestive of recent infection. Prospective studies on the outcome of these pregnancies are in progress but preliminary results suggest no connexion between fetal damage and ECHO 9 infection.

One of the challenging problems of general and obstetric practice is the management of suspected rubella in pregnancy. The development of diagnostic virological tests for rubella has helped greatly. However, these tests do not always provide clear-cut answers and in practice a proportion of cases still require the exercise of judgment and the assessment of probabilities. It is therefore important, and occasionally helpful, to know of the existence of other rubella-like conditions which do not necessarily carry the same risk to the exposed and infected pregnant woman and fetus. One of the commonest of these, occurring as epidemics at intervals of about four years, is caused by Echovirus 9 (ECHO 9). This enterovirus can cause mild febrile illness with rubella-like skin rashes, particularly in young children. Unlike rubella virus, no correlation between fetal damage and ECHO 9 infection in early pregnancy has been found (Rantasalo, Penttinen, Saxen, and Ojala, 1960; Kleinman, Prince, Mathey, Rosenfield, Bearman, and Syverton, 1962; Landsman, Grist, and Ross, 1964).

In the summer of 1973 an epidemic of ECHO 9 infection overlapped with an outbreak of rubella and provided, for the first time, an opportunity to apply tests for both infections in order to assess the extent to which Echovirus 9 might be involved in instances of exposure of pregnant women which could not be attributed to rubella.

1 Present address : Ayrshire Central Hospital, Irvine, Ayrshire, KA12 8SS

Received for publication 18 November 1974.
The peak of the rubella outbreak was in May-July and that of ECHO 9 in August-September (tables I and II). We examined for neutralizing antibodies to ECHO 9 virus samples of paired acute and convalescent phase sera collected during May-September 1973 from pregnant women with suspected rubella in whom tests for rubella did not indicate recent infection. Sera from 386 patients in the west of Scotland were available for study.

\begin{tabular}{|c|c|c|c|c|}
\hline & \multicolumn{2}{|c|}{$\begin{array}{l}\text { Communicable Diseases } \\
\text { Scotland Data }\end{array}$} & \multicolumn{2}{|c|}{$\begin{array}{l}\text { Regional Virus Laboratory } \\
\text { Data }\end{array}$} \\
\hline & Rubella & ECHO 9 & Rubella & $E C H O 9^{1}$ \\
\hline April & 18 & 0 & 6 & 0 \\
\hline May & 37 & 1 & 14 & 1 \\
\hline June & 63 & 11 & 17 & 2 \\
\hline July & 41 & 23 & 17 & 8 \\
\hline August & 28 & 37 & 4 & 9 \\
\hline September & 16 & 57 & 9 & 19 \\
\hline October & 13 & 38 & 3 & 6 \\
\hline
\end{tabular}

Table I Infections diagnosed virologically April-October 1973

${ }^{1}$ Isolations only

\begin{tabular}{lrrrrr}
\hline No. Sera Tested & May & June & July & August & September \\
\hline Total & 257 & 209 & 161 & 115 & 119 \\
Rubella positive & 4 & 12 & 7 & 3 & 3
\end{tabular}

Table II Regional Virus Laboratory data for rubella infections diagnosed virologically in pregnant women with suspected rubella May-September 1973 


\section{Methods}

Paired sera, usually 10-14 days apart, were stored at $-20^{\circ} \mathrm{C}$ until tested. For rubella antibodies, both the haemagglutination inhibition (HI) and complementfixation (CF) tests were used (Grist, Ross, and Bell, 1975). Firm diagnosis of recent rubella infection was based on the evidence of four-fold or greater rising antibody titres by HI or CF or on CF titres of 32 or greater.

Neutralizing antibodies to ECHO 9 virus were estimated using secondary rhesus monkey kidney tube cultures as described elsewhere (Bell, Stott, and Ross, 1964). The results were read on the third day of incubation and the antibody titres expressed as $50 \%$ endpoints. For purposes of analysis the finding of four-fold or greater rises in neutralizing antibody titres or titres of $>512$ was regarded as providing evidence of recent ECHO 9 virus infection.

\section{Results}

Diagnostic rising antibody titres to ECHO 9 were found in 12 , falling titres $(\Sigma 512 / 128)$ in one, and titres of $>512$ in 27 others (table III). In none of the 12 with rising titres was a rash recorded but three women with titres of $>512$ gave a history of 'rubelliform' rash. The temporal distribution of these $\mathbf{4 0}$ cases is shown in table IV. During the peak three months of the rubella epidemic ECHO 9 provided an alternative cause of illness in $5 \%$ of those examined.

\begin{tabular}{lrrrrl}
\hline & May & June & July & August & September \\
\hline $\begin{array}{l}\text { No. tested } \\
\text { Four-fold rising! }\end{array}$ & 100 & 100 & 35 & 101 & 50 \\
$\quad$ falling & 1 & 0 & 2 & 6 & 4 \\
$>512$ & 0 & 3 & 6 & 12 & 6 \\
256 & 0 & 4 & 3 & 5 & 3 \\
128 & 3 & 2 & 0 & 8 & 1 \\
64 & 3 & 4 & 0 & 5 & 1 \\
$16-32$ & 36 & 36 & 8 & 20 & 12 \\
$<16$ & 57 & 51 & 16 & 45 & 23 \\
\hline
\end{tabular}

Table III ECHO 9 neutralizing antibody titres in Rubella-negativa pregnant women May-September 1973

\begin{tabular}{lrrrrr}
\hline $\begin{array}{l}\text { No. Sera } \\
\text { Tested }\end{array}$ & May & June & July & August & September \\
\hline Total & 100 & 100 & 35 & 101 & 50 \\
$\begin{array}{l}\text { EHO 9 } \\
\text { positive }\end{array}$ & 1 & 3 & 8 & 18 & 10 \\
\hline
\end{tabular}

Table IV Regional Virus Laboratory data for ECHO 9 infections diagnosed serologically in rubella-negative pregnant women May-September 1973
In contrast to this, during the two peak months of the ECHO 9 epidemic at least $20 \%$ of these pregnant women originally suspected of having rubella gave evidence of ECHO 9 infection. These figures probably underestimate the true contribution of ECHO 9 virus since previous studies have shown that titres of $\$ 128$ are suggestive of recent infection (Bell, Stott, and Ross, 1964).

Cross reactions with other enteroviruses are less common in the neutralization test than in the $\mathrm{CF}$ test. However, since ECHO 11 virus was also epidemic in Scotland during the summer of 1973 (Epidemiology, 1974) neutralization tests against this virus were carried out on 12 parred sera which showed rising, high, or low ECHO 9 antibody titres. The results showed no correlation between antibody titres to the test viruses; only two patients with titres of $>512 />512$ showed moderately high (128) titres to ECHO 11 virus (Bell, 1974).

\section{Discussion}

Analysis of available data concerning the 1973 outbreak of rubella in Scotland suggested that the resulting increase in developmental anomalies among live-born children would be small, partly because virological tests facilitate selective termination of pregnancies where rubella damage is considered highly probable (Grist, 1973). The demonstration that a significant proportion of cases of rubella-like disease among pregnant women at the time was probably due to $\mathrm{ECHO} 9$ is also reassuring.

Most studies on ECHO 9 virus and developmental defects in the fetus have, of necessity, been retrospective. Our evidence of ECHO 9 infection in 40 women during early pregnancy has made possible a prospective study of this problem. Of the 12 women with diagnostic rising antibody titres, nine have been contacted by health visitors. All have produced babies with no obvious abnormalities. The results of further assessment of these babies at 9 months of age and of the outcome of the other pregnancies will be reported later.

We thank Dr D. Reid for permission to quote data from Communicable Diseases, Scotland, Dr E. M. Mackie, Assessment Unit, Royal Hospital for Sick Children, Glasgow, for follow-up studies, and Mrs R. Gray for valuable technical assistance.

References

Bell, E. J. (1974). Communicable Diseases Scotland, Weekly Report 23 March. V-VI.

Bell, E. J., Stott, J., and Ross, C. A. C. '(1964). Laboratory diagnosis 
of ECHO type 9 virus infection. Arch. ges. Virusforsch., 14, 147-159.

British Medical Journal. (1974). Epidemiology: echovirus type 11. Brit. med.J., 3, 123.

Grist, N. R. (1973). Rubella surveillance: recent data from Scotland. (Letter). Brit. med. J., 3, 636.

Grist, N. R., Ross, C. A. C., and Bell, E. J. (1975). Diagnostic Methods in Clinical Virology, 2nd edi., Blackwell, Oxford.

Kleinman, H., Prince, J. T., Mathey, W. E., Rosenfield, A. B., Bear- man, J. E., and Syverton, J. T. (1962). ECHO 9 virus infection and congenital abnormalities: a negative report. Pediatrics, 29, 261-269.

Landsman, J. B., Grist, N. R., and Ross, C. A. C. (1964). ECHO 9 virus infection and congenital malformations. Brit. J. prev. soc. Med., 18, 152-156.

Rantasalo, I., Penttinen, K., Saxén, L., and Ojala, A. (1960). ECHO 9 virus antibody status after an epidemic period and the possible teratogenic effect of the infection. Ann. Paediat. Fenn., 6, 175184. 